\title{
Five new species of Vernonieae (Asteraceae) from Espírito Santo, Brazil
}

\author{
Marcelo Monge ${ }^{1,2}$, Danilo Poso Volet ${ }^{1} \&$ João Semir ${ }^{1}$
}

\begin{abstract}
Espírito Santo is a hotspot of diversity in the Atlantic Forest in Brazil, where five new species of Vernonieae from the genera Cololobus, Lepidaploa, Lessingianthus, Piptocarpha, and Vernonanthura were found, and four of them occur in the municipality of Santa Teresa. These discoveries show that current knowledge on biodiversity in Espírito Santo is incipient, even in sites with decades of biological inventories, such as Santa Teresa. Here, all five species are described with comments about distribution, conservations status, phenology and taxonomic affinities. We also provide illustrations and a distribution map of the new species. According to the criteria of IUCN red list, Cololobus argenteus and Vernonanthura spathulata must be included in endangered (EN) category.
\end{abstract}

Key words: biodiversity hotspot, Compositae, Inselberg, tropical rain forest.

\begin{abstract}
Resumo
Espírito Santo é um hotspot de diversidade da Floresta Atlântica no Brasil, onde cinco novas espécies de Vernonieae dos gêneros Cololobus, Lepidaploa, Lessingianthus, Piptocarpha e Vernonanthura foram encontradas, e quatro delas ocorrem no município de Santa Teresa. Essas descobertas mostram que o conhecimento atual em biodiversidade no Espírito Santo é incipiente, mesmo em locais com décadas de inventórios biológicos, como em Santa Teresa. Aqui, todas as cinco espécies são descritas com comentários sobre distribuição, status de conservação, fenologia e afinidades taxonômicas. Nós também fornecemos ilustrações e um mapa de distribuição das novas espécies. De acordo com os critérios da lista vermelha da IUCN, Cololobus argenteus e Vernonanthura spathulata devem ser incluídas na categoria de ameaçada (EN). Palavras-chave: hotspot de biodiversidade, Compositae, Inselberg, floresta tropical úmida.
\end{abstract}

\section{Introduction}

The Atlantic Forest is the second largest tropical moist forest in South America (OliveiraFilho \& Fontes 2000) and it comprises a very complex natural landscapes driven by geo-climatic factors, especially by rainfall seasonality and temperature (Oliveira-Filho \& Fontes 2000). The Atlantic Forest, in a wide sense, encompasses several types of vegetation, ranging from rain forests, semideciduous forests, deciduous dry forests, and its associated vegetations, as well as granitic inselbergs and tropical highland grasslands. Currently, the natural vegetation is estimated to account for around $12.5 \%$ of its original area (Fundação SOS Mata Atlântica \& INPE 2015) and the remaining forest occurs in small isolated fragments (Morellato \& Haddad 2000; Ribeiro et al. 2009). According to Sala et al. (2000), land use is the main factor for biodiversity loss. Nevertheless, the Atlantic Forest is the richest vegetation of angiosperms in Brazil, with 15,001 species and nearly $50 \%$ of them are endemic (BFG 2015). Thus, the Atlantic Forest is considered one of the biodiversity hotspots (Myers et al. 2000) and consequently it has high priority in the conservation status (Myers et al. 2000; Ribeiro et al. 2009).

Espírito Santo is placed in a transitional zone between northern and southern parts of the Atlantic Forest. It is a recognized diversity center (Carnaval \& Moritz 2008; Thomaz 2010) for flowering plants (Thomaz \& Monteiro 1997; Saiter \& Thomaz 2014), butterflies (Brown 1972), birds (Simon \& Padovan 2000; Simon 2009), and mammals (Moreira et al. 2008). However, the

\footnotetext{
${ }^{1}$ Universidade Estadual de Campinas, Depto. Biologia Vegetal, Prog. Pós-graduação em Biologia Vegetal, R. Monteiro Lobato 255, Cidade Universitária Zeferino Vaz, Barão Geraldo, 13.083-970, Campinas, SP, Brazil.

${ }^{2}$ Author for correspondence: marcelomonge@gmail.com
} 
deforestation pattern in the state is similar to that in other Brazilian regions. Deforestation was caused by several economic cycles, leading to degradation of the environment as whole, including vegetation, soil and water (CEDAGRO 2012).

During the last 30 years, the collecting efforts in Espírito Santo, especially in restingas, montane ecosystems and "Tabuleiro" forests, allowed the discovery of several new plant species, such as herbs (Fraga \& Kollmann 2003; Leme et al. 2010; Bacci et al. 2016), shrubs (Camargo \& Goldenberg 2011; Fraga \& Guimarães 2014), trees (Sobral 2005; Sales et al. 2006), and lianas (Imig \& Cervi 2014; Almeida \& Amorim 2015).

Vernonieae Cass. is a tribe with around 120 genera and more than 1,000 species, distributed mainly in tropical areas (Robinson 2007; Keeley \& Robinson 2009) and the Atlantic Forest is one of its diversity center (BFG 2015). Currently, Vernonieae has 21 subtribes, such as Lepidaploinae S.C.Keeley \& H.Rob., Piptocarphinae H. Rob., F. Bohlmann \& R.M. King, and Vernoniinae Cass. ex Dumort. (Keeley \& Robinson 2009), which represent divergent lineages within the tribe (Keeley et al. 2007; Keeley \& Robinson 2009).

This study describes one new species for each of the following genera: Cololobus, Lepidaploa, Lessingianthus, Piptocarpha, and Vernonanthura, belonging to three different subtribes (Lepidaploinae, Piptocarphinae, and Vernoniinae) collected in Espírito Santo State, southeastern Brazil.

\section{Materials and Methods}

The taxonomical and morphological analyses were based on collections stored at the herbaria: MBML, RB, SPF, UEC, and VIES (Thiers, continuously updated). The morphological descriptions followed Smith (1981, 1982, 1984), Smith \& Jones (1987), Robinson (1988, 1990, 1992, 1994, 1999, 2002), and Smith \& Coile (2007). General morphological terms were in accordance to Radford et al. (1974) and LAWG (1999). The vegetation is classified according to IBGE (2012) and Garbin et al. (2017). Measurements, colors, and other details are based on herbarium specimens and observations were made on Olympus SZX16 stereo microscope. The extent of occurrence (EOO) and the area of occupancy (AOO) were estimated with the Geospatial Conservation Assessment Tool-GeoCAT (Bachman et al. 2011) to assess the conservation status, following IUCN (2016) criteria.

\section{Results and Discussion}

Lepidaploinae is one of the newest subtribes. It comprises 14 genera and almost 300 species, mostly distributed in neotropics, but with one pantropical genus (Keeley \& Robinson 2009). Lepidaploinae is characterized by simple or t-shaped trichomes, seriate cymose inflorescences, sessile or pedicellate capitula, persistent involucral bracts, epaleaceous receptacle, anthers often with glands, cypsela with elongate or subquadrate raphids, outter pappus capillary bristles, scale-like or crown-shaped, and tricolporate pollen, echinate, often lophate. Two important genera of the subtribe are Lepidaploa (Cass.) Cass. and Lessingianthus H.Rob., accounting for almost $75 \%$ of species the subtribe and two of the new species presented here belongs to one of each genera.

Lepidaploa aurata M.Monge \& Semir, sp. nov. Type: BRAZIL. ESPÍRITO SANTO: Santa Teresa, distrito 25 de Julho, Bela Vista, propr. Sr. Jose Zucolotto, 29.IV.2005, fl. and fr., A.P. Fontana et al. 1406 (Holotype: MBML!. Isotype: RB!).

Fig. 1

Lepidaploa aurata has unique features that distinguishes it from the remaining species of the genus, such as golden trichomes on leaves and branches, leaf blades setose on lamina and strigillose on venation, congest seriate cymes, involucral bracts with mucronate apex, receptacle honeycombed, and lanceolate bristles of outer pappus series.

Shrub, $1 \mathrm{~m}$ tall. Branches striate, densely strigilose, golden, rufous, trichomes without a bulbous base. Leaves alternate, petiolate, petiole 2-3.6 mm, lamina $(2.5-) 4.5-15 \times(1-) 2-3.5 \mathrm{~cm}$, lanceolate, elliptic, base rounded, sometimes asymmetric, margin sub-revolute, smooth, apex acuminate, with small mucron; concolorous, abaxial surface, densely setose, thinner golden trichomes with small bulbous base, strigilose on venation, adaxial surface setose, thinner golden trichomes with small bulbous base, glabrescent, bulbous base persistent, strigillose on the venation; venation eucamptodromous, prominent abaxially and adaxially. Inflorescences in small seriate cymes, congested, apical and axillary, 3-5 capitula per cyme. Capitula 9-13 mm, sub-sessile, 2.5 $\mathrm{mm}$, strigilose, golden, subinvolucral bracts at the capitula base, leaf shape; involucre 7.5-9 × 4-6 $\mathrm{mm}$, cylindrical to narrowly campanulate, 6 series, involucral bracts straight lanceolate to narrowly lanceolate, purple, margins ciliate, sometimes 


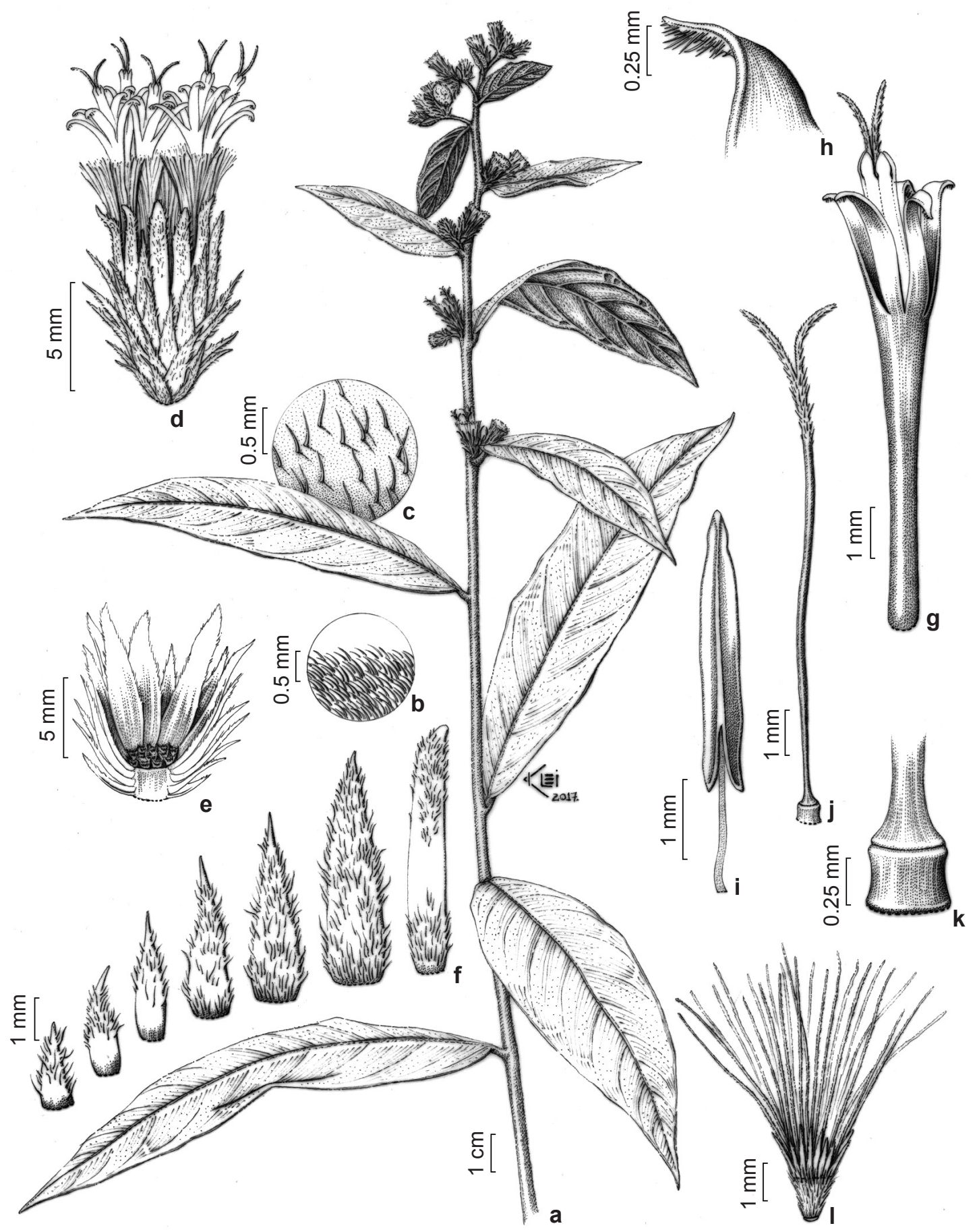

Figure 1 - a-l. Lepidaploa aurata - a. reproductive branch; b. trichomes adaxially on leaves; c. trichomes abaxially on leaves; d. capitulum; e. tranverssal view of the capitulum; f. involucral bracts; g. corolla, anthers, and style; h. apex of corolla lobes; i. anther; j. style; k. expanded base of the style; 1. cypsela. (A.P. Fontana et al. 1406). 
erose, apex mucronate, pilose; receptacle plane, honeycombed, sparsely pubescent. Flowers ca. 16, 10-12 mm long, corolla, 8-9 mm, tubulose, tube $6 \mathrm{~mm}$, lobes $3 \mathrm{~mm}$, lanceolate, trichomes at the apex of the lobes; anther $3.5 \mathrm{~mm}$, sagittate base, non glandular, apical appendage lanceolate, non glandular; style base expanded, branches acute, sweeping hairs reaching below the bifurcation, unicellular, narrowly pyriform, apex acute. Cypselae, 1.5-2 mm, striate, densely pubescent, dark brown; carpopodium $0.2 \mathrm{~mm}$ long, brown; pappus 2 series, cream, inner row $6 \mathrm{~mm}$, bristle, barbellate, outer row $1.3 \mathrm{~mm}$ long, dorsiventraly compressed, lanceolate, ciliate.

Distribution, ecology, and conservation status: Lepidaploa aurata is known only from the type locality, in the " 25 de Julho" district in the Santa Teresa municipality. The region where the municipality is located, central highland, is categorized as extreme priority for conservation (IPEMA 2005). Lepidaploa aurata grows in Ombrophyllous Montane Forest on hillside in the Atlantic Forest Domain (Fig. 2). The conservation status is data deficient (DD), because there is only one collection of this new taxon. However, L. aurata was collected outside of conservation units where vegetation is highly fragmented, raising concerns about its natural populations. New efforts to search for natural populations should be encouraged to evaluate its conservation status.

Phenology: The material with flowers and young fruits was collected in April.

Etymology: The specific epithet refers to the golden trichomes in the branches and leaves.

Taxonomy: Lepidaploa aurata is differentiated from other species of the genus by the golden trichomes on leaves and branches, leaf blades abaxially setose and strigillose on venation, leaf blades adaxially setose trichomes with bulbous base, and strigillose on venation, congest seriate cymes, involucral bracts with mucronate apex, receptacle honeycombed, cypselae with carpopodium and bristles of outer pappus series oblong.

On the one hand, Lepidaploa aurata is morphologically similar to L. davidsmithii H.Rob. by its lanceolate and elliptic leaves, golden trichomes in branches and leaves, rounded bases, and acuminates apex. However, L. aurata differs from $L$. davidsmithii by its young leaves covered abaxially by golden setose trichomes with bulbous base (vs. young leaves villose, whitish); concolorous leaves (vs. discolorous); leaves adaxially setose, golden trichomes glabrescent (vs. adaxially sparsely puberulous, glabrescent); inflorescences in a small seriate cyme ( $v s$. ample scorpioid cyme); 3-5 capitula per inflorescence, (vs. 10-23 capitula per inflorescences); single capitule per node ( $v s$. geminate capitula, 2-3 per node); longer capitula, 9-13 mm [vs. smaller 4.5-6.5(8.6) $\mathrm{mm}$; ; and finally by its distribution in southeastern Brazil (vs. Peru).

On the other hand, compared to Brazilian species of the genus, Lepidaploa aurata resembles L. chamissonis (Less.) H.Rob. and L. persericea H.Rob. by the shrubby habit, trichomes on both sides of the leaves, and by the presence of the leafy subinvolucral bracts. However, the new species differ by the golden and rufous trichomes ( $v s$. whitish, sometimes silvery); concolorous leaves (vs. discolorous); secondary venation prominent adaxially ( $v s$. sulcate); inflorescences in a congested seriate cyme ( $v s$. ample seriate cyme); single

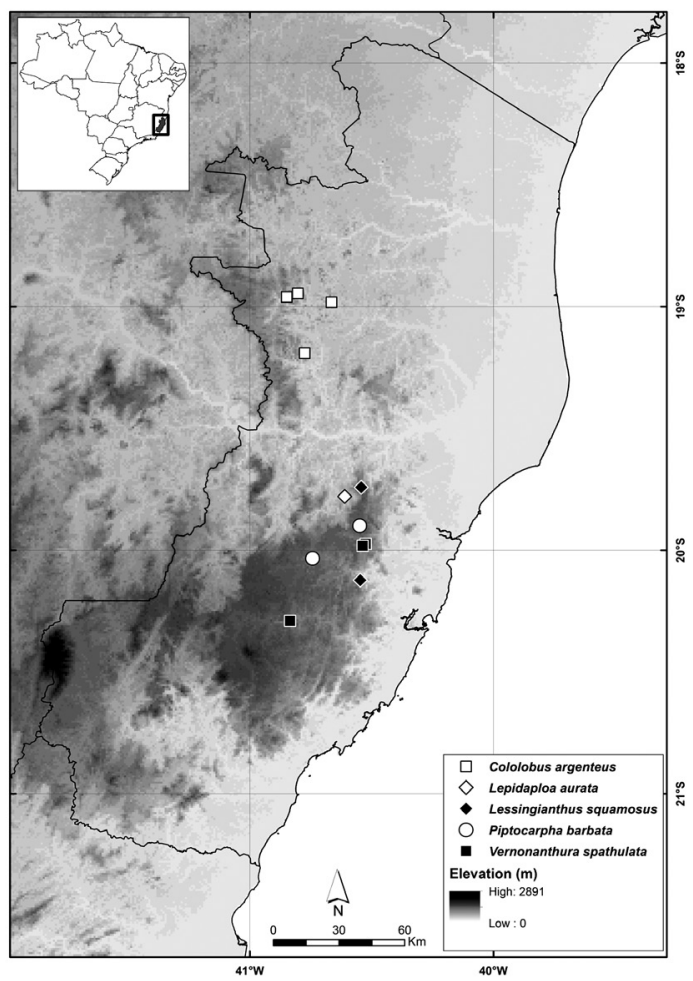

Figure 2 - Distribution map of Espírito Santo indicating where Cololobus argenteus, Lepidaploa aurata, Lessingianthus squamosus, Piptocarpha barbata, and Vernonanthura spathulata were collected. 
capitule per node ( $v s$. often 2 capitula per node, but also occur single capitule); taller involucre 7-9 $\mathrm{mm}$ (4-5 $\mathrm{mm}$ for L. chamissonis and 7-8 $\mathrm{mm}$ for L. persericea); involucral bracts with concolorous margins ( $v s$. often discolorous, yellow, but also occur concolorous); and purple colored (vs. green).

Lessingianthus squamosus M.Monge \& Semir, sp. nov. Type: BRAZIL. ESPÍRITO SANTO: Santa Leopoldina, Bragança, prop. Assunta Salvador, 400-600 m altitude, 207'23"S, 40³2'47'W, 17.XII.2006, fl. and fr., L.S.F. Magnano et al. 995 (Holotype: MBML 028532!. Isotype: SPF 191737 !).

Fig. 3

Lessingianthus squamosus differs from other species of the genus by the presence coriaceous leaves, with apically serrate margins, semicraspedodromous venation, leafy subinvolucral bracts, involucral bracts with yellow margins, mucronated apex, longer flowers, and annular outer series of the pappus.

Shrub, 1-1.5 m tall. Branches striate, puberulous, glabrescent; leaf scars cymbyform, open v-shaped, with three vascular traces, one central, larger, two lateral ones, smaller. Leaves alternate, deciduous, petiolate, petiole (3-)5-7.5(9.5) mm, lamina (2-)3.5-6.5 × (1-)2-2.6 cm, coriaceous, oblanceolate, elliptic, base attenuate, sometimes asmymetric, margin sub-revolute, serrate apically, apex acute, with small mucron, concolorous, abaxial and adaxial surface setose, early glabrescent, glandular dots golden; venation semicraspedodromous, impressed abaxially, proeminent adaxially. Inflorescences corymbiform, apical, up to 5 capitula. Capitula $1.6-2.3 \mathrm{~cm}$, pedunculate, peduncle $(0.5-) 1-1.5(-5.5) \mathrm{mm}$, puberulous, subinvolucral bracts at the capitula base, leaf-like; involucre 1.4-1.6 × 1.5-2 cm, broad campanulate, $8-10$ series, involucral bracts shallowly deltate, ovate, lanceolate, pyriform, straight oblong, green, margins yellow, ciliate, apex mucronate, mucronulate, arachnoid, glabrescent, sparse glandular dots; receptacle plane, fimbriate. Flowers 76-79, corolla 16-17 mm long, tubulose, magenta, tube $10 \mathrm{~mm}$, glabrous, lobes 5-6 mm, lanceolate, glandular dots at the lobes; anther 5 $\mathrm{mm}$, sagittate base, non glandular, apical appendage lanceolate, non glandular; style base not expanded, branches acute, sweeping hairs reaching below the bifurcation, unicellular, terete, apex acute. Cypselae $1.7 \mathrm{~mm}$, estriate, glabrous, brown, carpopodium not developed; pappus 2 series, cream, inner series 7 $\mathrm{mm}$, bristles barbellate, outer row ringed, $0.4 \mathrm{~mm}$.
Distribution, ecology and conservation status: Lessingianthus squamosus is known only from the municipalities of Santa Leopoldina and Santa Teresa. It grows in granitic rocky outcrops, scrubs, and forest edges of Ombrophyllous Montane Deciduous Forest on hillside in the Atlantic Forest around 400-1,000 $\mathrm{m}$ above sea level (Fig. 2). Although, IUCN (2016) criteria for the new species is data deficient, due to the few samples collected. This type of environment is very common in Caparaó, central highland, and northwestern regions, allowing to occur unknown populations in other areas. Therefore, new efforts to search for natural populations should be encouraged.

Phenology: Flowering and fruiting simultaneously between December to May.

Etymology: The specific epithet is due to the notable green involucral bracts, with yellow margins, and mucronate apex, resembling a scale. Additional specimens examined (Paratypes): BRAZIL. ESPÍRITO SANTO: Santa Leopoldina, Luxemburgo, Pedra Preta, 1,020 m altitude, 15.III.2005, fl. and fr., A.P. Fontana et al. 1145 (MBML!, SPF!). Santa Teresa, Julião, owner Mr. João Luiz de Rodrigues de Souza, $645 \mathrm{~m}$ altitude, 1944'30,7'S, 40³2'32,9'W, 23.II.2007, fl. and fr., A.P. Fontana K.A. Brahim 2970 (MBML!, RB!).

Taxonomy: Lessingianthus squamosus is easily differentiated from the remaining species of the genus by the presence coriaceous leaves, glabrescent, with apically serrate margins, semicraspedodromous venation, involucral bracts with yellow margins, mucronate and mucronulate apex, longer flowers, and ringed outer series of the pappus. Lessingianthus squamosus also has another uncommon feature in the genus: the presence of leaf-like subinvolucral bracts at the base of each capitulum, also present in Dasyphyllum vepreculatum (D.Don) Cabrera.

Lessingianthus squamosus is morphologically similar to L. bardanoides (Less.) H. Rob. due to the shrubby habit, larger capitula, with subinvolucral bracts at the capitula base, green involucral bracts with yellow margins and pungent mucron, and magenta flowers. Neverthless, L. squamosus is differentiated by the puberulous branches ( $v s$. pilose); petiolate leaves (vs. sessile); setose, but glabrescent leaves ( $v s$. pilose, non-glabrescent); pedunculate capitula ( $v s$. sessile); terminal capitula (vs. axillary); involucral bracts apically terminating abruptly in a mucron (vs. apex smoothly apically terminating with a mucron), and outer pappus row ringed ( $v s$. small scales). 


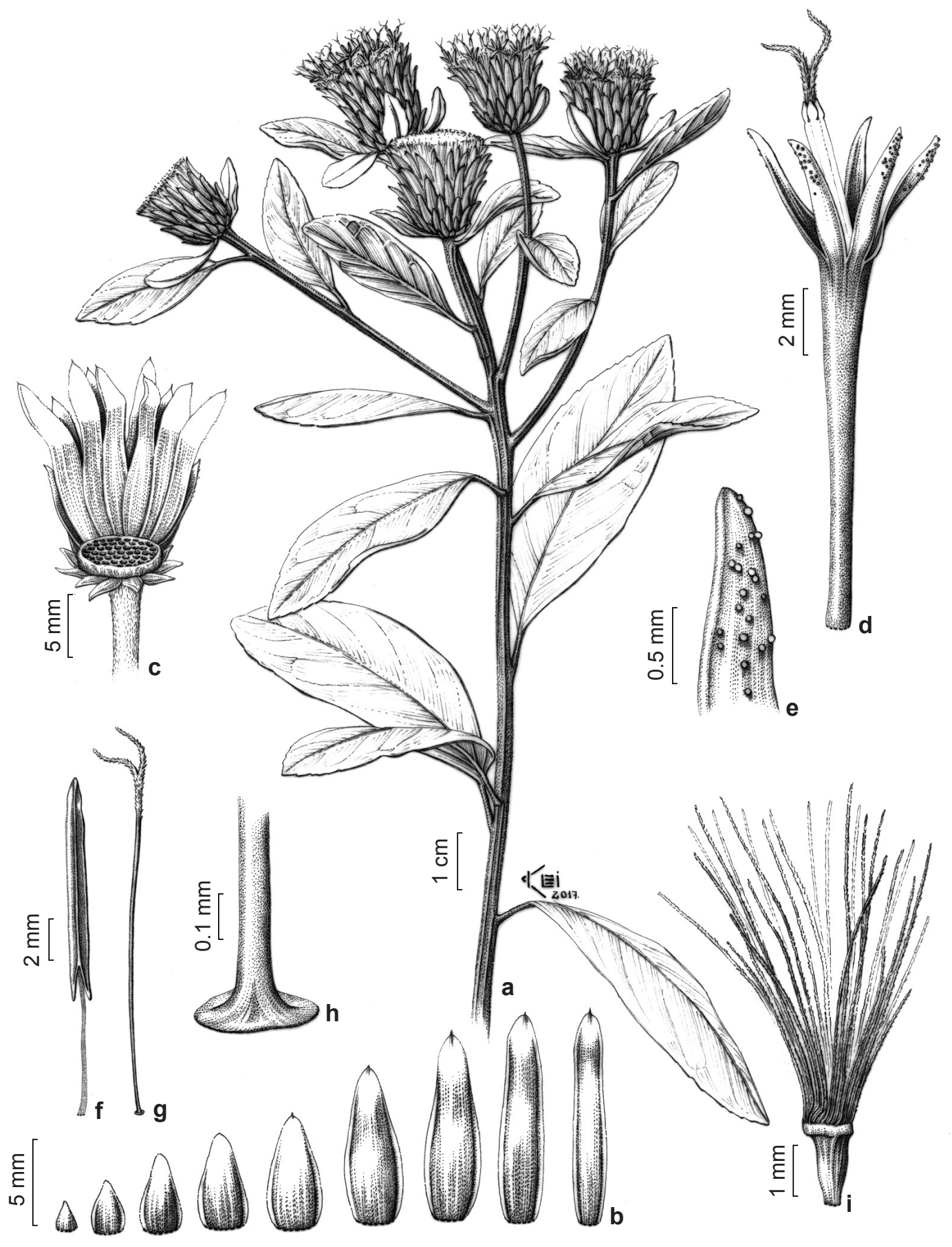

Figure 3 - a-i. Lessingianthus squamosus - a. reproductive branch; b. involucral bracts; c. transverssal view of the capitulum; d. corolla, anthers, and style; e. apex of corolla lobes; f. anther; g. style; h. not expanded base of the style; i. cypsela. (L.S.F. Magnano et al. 995). 
The subtribe Piptocarphinae is composed by 10 genera and 120 species, and restricted to the tropical Americas (Keeley \& Robinson 2009). The subtribe can be recognized by the lianescent, shrubby, or tree habit, stellate or lepidote trichomes, leaves alternate or opposite, inflorescences in lateral glomerules or in branching panicles, deciduous inner involucral bracts, fewer flowers per capitulum, anther often without glands, style shafts with multicelullar trichomes, with rounded apex, and tricolporate, echinate, sublophate pollen (Robinson et al. 1980; Robinson 1999; Keeley \& Robinson 2009). Piptocarpha R. Br. alone accounts for more than one third of the subtribe diversity and here we present a new species.

Piptocarpha barbata Volet \& Semir, sp. nov. Type: BRAZIL. ESPÍRITO SANTO: Santa Teresa, Reserva Biológica Augusto Ruschi, 1953.582'S, 40³2.754'W, 22.VIII.2012, fl., T.B. Flores \& G.O. Romão 1022 (Holotype: UEC! Isotype: ESA 120205!).

Fig. 4

Piptocarpha barbata is morphologically similar to Piptocarpha oblonga (Gardner) Baker and differs by its golden stellate trichomes of leaves and the presence of 2-4 trichomes in the apex of corolla lobes, unique in the genus.

Climber. Branches, flexuous, cylindrical, costate, dark-brown, highly stellate-tomentose, golden. Leaves alternate, petiolate, petioles $0.7-1.1 \mathrm{~cm}$ long, cylindrical, stellate-tomentose; lamina 6.4-8.9 × 2.8-3.7 cm, chartaceous, oblong, elliptic, ovate to sub-oblong, base rounded, margin smooth, apex acute, acuminate; abaxial surface stellate trichomes, with sessile or stalked, sparse, golden, adaxial surface stellate-tomentose only on primary vein, glabrescent, concolorous; venation brochidodromous, 7-10 pairs secondary veins alternate or opposite. Inflorescences axillary, glomerular, 9-19 capitula. Capitula 9.2-12.7 $\times 3.9-5.3 \mathrm{~mm}$, very short peduncle, stellatetomentose; involucre $9.2-12.3 \times 3.9-5.3 \mathrm{~mm}$, fusiform, densely tomentose; involucral bracts in 6-8 series, decidual, outer series 2.1-5.1 $\times$ 1.1-1.9 mm, ovate to elliptic, ochraceous, apex brown-ferruginous, obtuse to rounded, tomentose, margins ciliate; inner series 5.5-7.9 × 1.4-1.7 $\mathrm{mm}$, oblong to lanceolate, ochraceous, apex obtuse to rounded, margin ciliate at apex, brownferruginous, tomentose to sub-villous. Flowers 3 , corolla 5.3-6.1 mm long, tubulose, white, tube 0.4-1.5 mm long, lobe 4-4.6 $\mathrm{mm}$ long, apex with 2-4 trichomes per lobe and glandular dots; anthers
2.8-3.4 mm long, caudate, basal appendage $0.5-0.9 \mathrm{~mm}$ long, elongated, papillate at the tip, filaments $1.3-2.1 \mathrm{~mm}$ long; styles 5-5.8 mm long, dorsal surface with multicellular, apically rounded collecting trichomes. Cypselae (immature) 4.5-5.3 mm long, costate, carpopodium $0.3 \mathrm{~mm}$, cream-colored; pappus, white, biseriate, filiform, inner series $6.8-7.1 \mathrm{~mm}$ long, external series $0.5-0.9 \mathrm{~mm}$.

Distribution, ecology, and conservation status: Piptocarpha barbata is known only in two sites, one in the municipality of Santa Teresa, in the Reserva Biológica Augusto Ruschi, and another in the municipality of Santa Maria de Jetibá, in a private property (Fig. 2). The species grows in the Ombrophilous Montane Forest, at altitudes between $800-900 \mathrm{~m}$. The new species is evaluated as data deficient (DD) of IUCN (2016) criteria, due to few collections. However, this vegetation type is one of the most widespread in high montane and Caparaó regions in the state, thus probably there are several unknown populations.

Phenology: The specimens were collected with young flowers in August.

Etymology: The name of the new species refers to the trichomes in the apex of corolla lobes. Aditional specimens examined (Paratypes): BRAZIL. ESPÍRITO SANTO: Santa Maria de Jetibá, Terreno de Paulo Seik, 21.VIII.2003, fl., L. Kollmann \& M.V.S. Berger 6274 (SPF!).

Taxonomy: According to the classification proposed by Smith \& Coile (2007) for the genus, Piptocarpha barbata belongs to Piptocarpha subgenus Hypericoides because anthers have auricles elongated, slender, with papillated apex. The new species is better placed in section Macrolepideae serie Pyrifoliae, because it has stellate trichomes on the leaves, corolla tubes smaller than the lobes, and sessile capitula.

Piptocarpha barbata is the only species of the genus that presents trichomes at the apex of corolla lobes ( $2-4$ trichomes per apex). The species also presents involucres densely tomentose, and adaxial leaf surface with sessile or stalked golden stellate trichomes. It is morphologically similar to P. oblonga (Gardner) Baker due to the scandent habit, oblong to elliptical leaves, glomeruliforms inflorescences and capitula with three flowers, but it differs by the golden stellate trichomes on the leaves ( $v s$. cinereous lepidote trichomes), leaves concolorous (vs. discolorous), and fewer than 20 capitula per inflorescence ( $v s$. more than 20 capitula). 


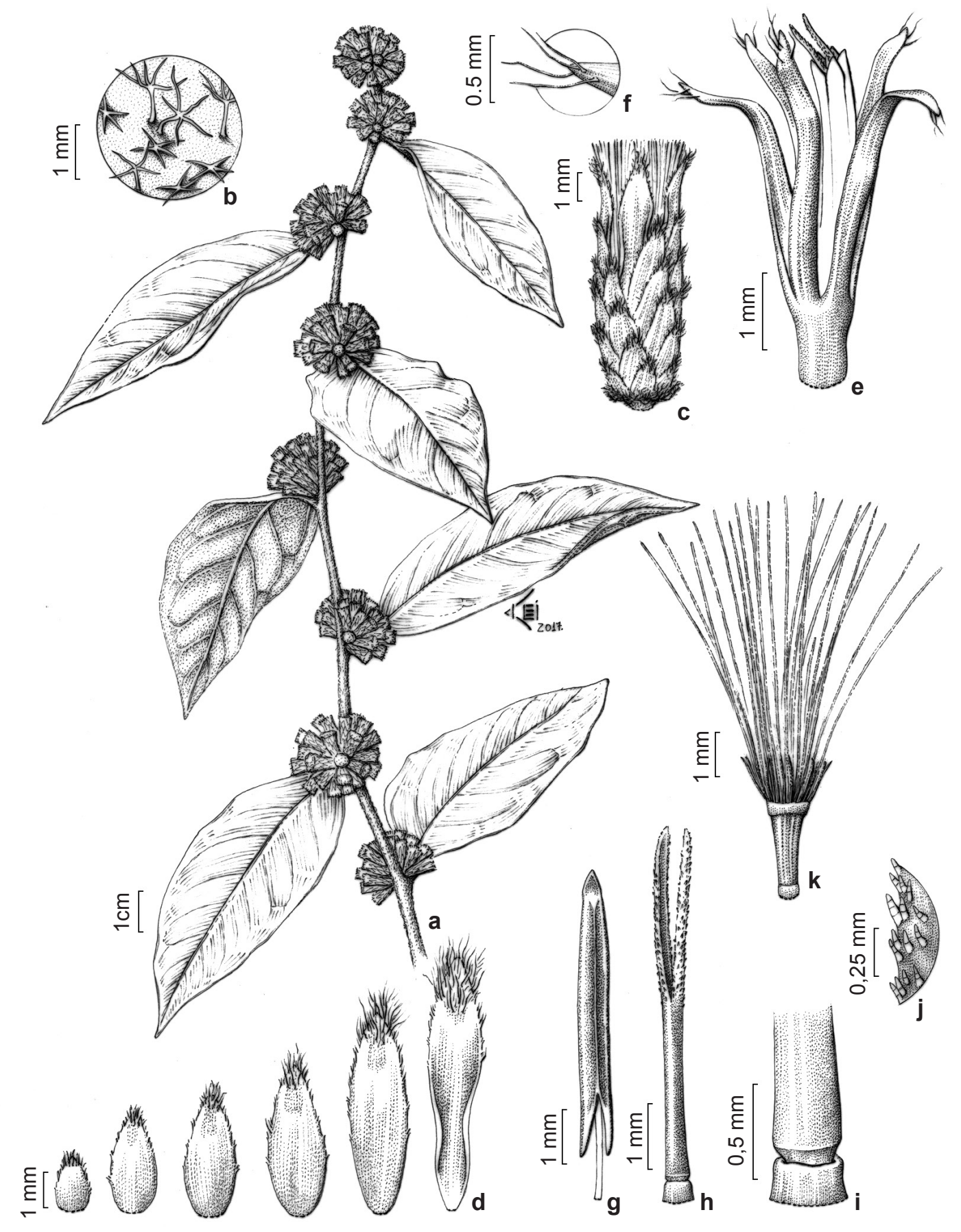

Figure 4 - a-k. Piptocarpha barbata - a. reproductive branch; b. trichomes; c. involucre; d. involucral bracts; e. corolla; f. detail of the lobes; g. anther; h. style; i. base of the style; j. sweeping hairs; k. cypsela. (T.B. Flores \& G.O. Romão 1022). 
Finally, Vernoniinae is composed by nine genera and nearly 200 species, most restricted to the neotropics, with only one genus in Africa (Keeley \& Robinson 2009). The subtribe is characterized by alternate leaves, seriate cymose or scorpiod inflorescences, pedicellate capitula, corolla lobes with multiple resin ducts, anther with glands, cypselae with subquadrate raphids, pappus of capillary bristles, and pollen tricolporate, echinate, usually sublophate (Keeley \& Robinson 2009). Cololobus H.Rob. and Vernonanthura H.Rob. belong to Vernoniinae, the former is a very small genus with only three species and the latter comprises almost 80 species. Here, we present two new species one for each genus.

Cololobus argenteus M.Monge \& Semir, $s p$. nov. Type: BRAZIL. ESPÍRITO SANTO: Águia Branca, Rochedo, prop. Arlindo Breda, 400-500 $m$ altitude, 18 ${ }^{\circ} 56^{\prime} 45^{\prime}$ 'S, 40 48'10"W, 16.V.2007, fl. and fr., V. Dreumer et al. 3902 (holotype: MBML!).

Fig. 5

Cololobus argenteus has several unique features that distinguish it from the other species of the genus, such as the densely sericeous, panose, villose, tomentose, greyish trichomes, leaves $(3.5-) 4-12(-13.4) \times 1.2-3.2(-4) \mathrm{cm}$, and pinkish pappus.

Subshrubs, up to $1 \mathrm{~m}$ tall, caespitose, erect. Branches striate, internodes 1.8-4(5) $\mathrm{mm}$, densely sericeous, panose, villose, tomentose, greyish, silvery; leaf scars carinate, open v-shaped, with five vascular bundles, central and distal ones rounded, internal rectangular, with tuft of velutinous trichomes on the leaf scars. Leaves spirally alternate, imbricate, base with sheath, conspicuous in basal leaves, petiolate or subsessile, petiole (2-)4-8 $\mathrm{mm}$ long, lamina $(3.5-) 4-12(-13.4) \times 1.2-3.2(-4) \mathrm{cm}$, lanceolate, elliptic, chartaceous, base attenuate, margin smooth, plane, apex acute; abaxial and adaxial surfaces panose, sericeous, villose, more dense in the primary vein, greyish, silvery; venation brochidodromous, principal venation proeminent abaxially, impressed adaxially, secondary venation not easily seen, covered by trichomes. Inflorescences very long panicles, lateral racemes composed by $2-10$ capitula, branchlets $3.5-12 \mathrm{~cm}$ long, subtended by bracts. Capitula sub-sessile to pedunculate, peduncle (1.3-)2.9-8.4(-12.7) $\mathrm{mm}$ long, villose; involucre 5.5-7.5 × 8.3-13 mm, wide campanulate or cupuliform; involucral bracts in 5 series, persistent, $3-5 \times 1.3-2 \mathrm{~mm}$, widely ovate, ovate, lanceolate, apex acuminate, outter erect, inner slightly recurved, margins ciliate or smooth, villose, arachnoid, glabrescent, with golden glandular dots; receptacle slightly convex, paleaceous, margins erose. Flowers 32, 10-11 mm, corolla $7-7.5 \mathrm{~mm}$, tubulose, pink, magenta, tube 5-6 mm, glabrous, lobes $1-1.5 \times 0.68-0.78 \mathrm{~mm}$ long, lanceolate, with glandular dots; anthers 2 $\mathrm{mm}$, sagittate base, apical appendage elliptic, non glandular: style base expanded, branches acute, sweeping hairs reaching below the bifurcation, unicellular, narrowly pyriform. Cipselae, $1.5 \mathrm{~mm}$, striate, sparsely pubescent, glabrescent, glandular dots at the apex; carpopodium absent; pappus 2 series, pink, inner row $5 \mathrm{~mm}$ long, bristles terete, barbellate, outer row $1 \mathrm{~mm}$ long, straight lanceolate, bristles dorsoventrally flattened, barbellate, acute apex.

Distribution, ecology, and conservation status: Cololobus argenteus is known in the municipalities of Águia Branca and Pancas, in the Pontões Capixabas Natural Monument, in the northwestern region, categorized as very high priority for conservation (Ipema 2005). Cololobus argenteus grows in inselbergs of granitic rocks, between $300-800 \mathrm{~m}$ of altitude (Fig. 2), which is a very harsh environment, because of low water retention, total or partial absence of soil, nutrient scarcity, exposure to wind, wide thermal amplitude, and high UV levels. These environmental filters confers highly specialized flora to this habitat (Larson 2000; Porembski 2007). Cololobus argenteus is categorized as endangered (EN) according to the criteria B1ab (i, iii) + 2ab (ii, iii) of IUCN (2016) with an estimated Area of Occupancy (AOO) of $16 \mathrm{~km}^{2}$ and an Extension of Occurrence (EOO) of 264.718 $\mathrm{km}^{2}$. The conservation unit of Pontões Capixabas has several areas of Coffea sp. plantations in lowlands, where occasional fires may deteriorate the remaining vegetation on inselbergs, such as the inselberg of Pedra do Rudio in Santa Teresa and many other sites in the state.

Phenology: Flowering and fruiting simultaneously from April to August.

Etymology: The species name is due to the remarkable silvery trichomes in the entire plant.

Vernacular: Algodão-do-campo, verbasco, prateadinha.

Additional specimens examined (Paratypes): BRAZIL. ESPÍRITO SANTO: Águia Branca. Santa Luzia, Pedra da Bandeira, owner Ciro Ferreira, $18^{\circ} 58^{\prime} 76^{\prime}$ 'S, 40³9'93"W, $362 \mathrm{~m}$ altitude, 26.IV.2008, $\mathrm{fl}$ and fr., A.P. Fontana et al. 5047 (MBML!, BHCB); 


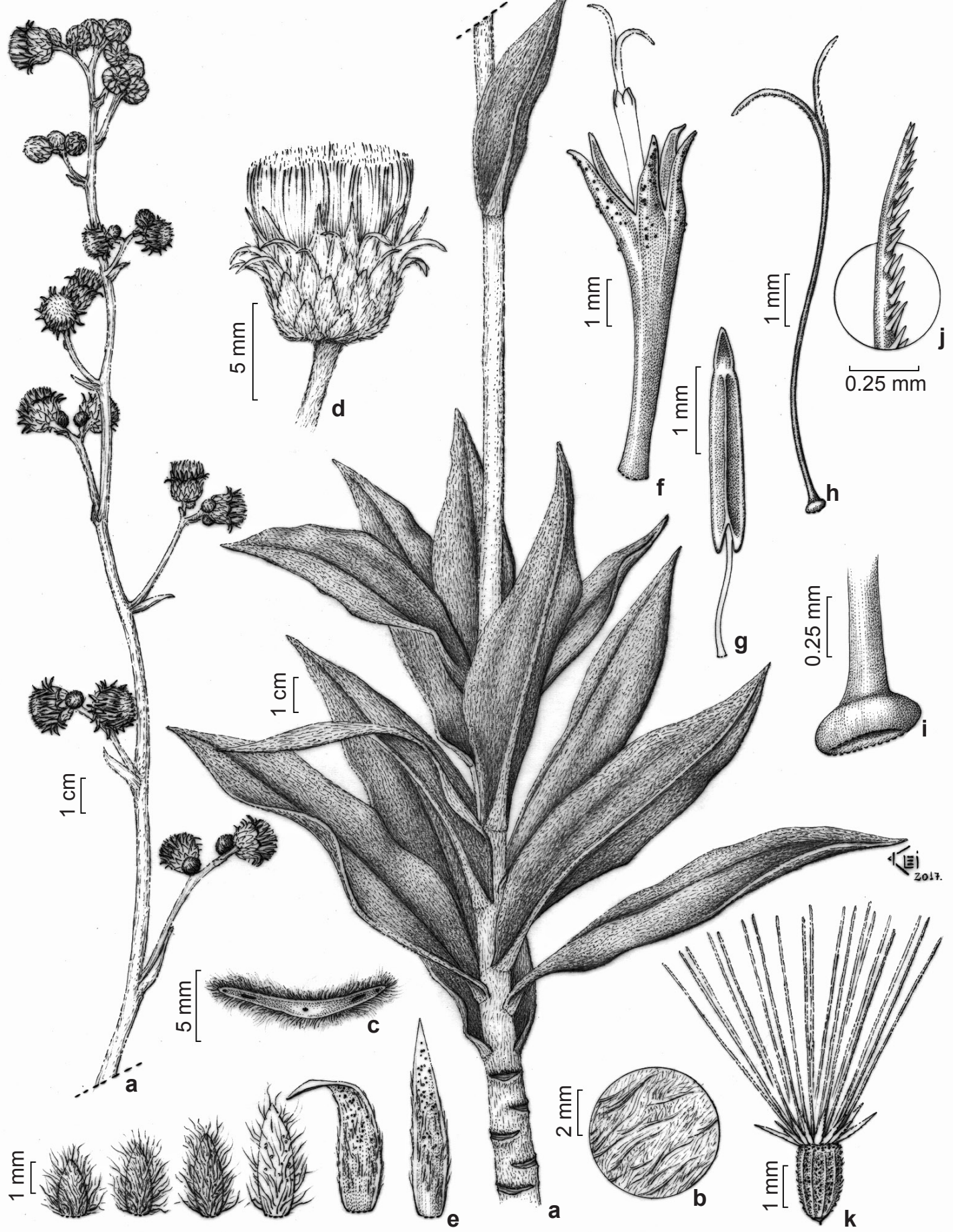

Figure 5 - a-k. Cololobus argenteus - a. reproductive branch; b. trichomes; c. cross section of leaf seath, with five vascular bundles; d. involucre; e. involucral bracts; f. corolla; g. anther; h. style; i. expanded base of the style; j. sweeping hairs; k. cypsela (V. Dreumer et al. 3902). 
region of Três Pontões, 1897'39'S, 4070'75"W, fl. and fr., H.V. Pinto Jr. 156 (SAME, RB!). Pancas, Parque Nacional dos Pontões Capixabas, Lajinha, owner Vidal Krausse, 19¹1'293'S, 4046'296”W, 5.VIII.2006, fl. and fr., A.P. Fontana et al. 2330 (MBML!, RB!).

Taxonomy: As previously mentioned, Cololobus H.Rob. is a small genus restricted to the coast and some parts of southeastern Brazil (Robinson 1999). It occurs on granitic inselbergs, in small rifts. According to Robinson (1994) it belongs to Vernoniineae, due to pollen type A, glabrous corolla, enlarged basal style node, and persistent involucral bracts (Robinson 1994, 1999). Cololobus has several unique morphological features, such as the short corolla lobes (Robinson 1994), leaves with sheath, paleaceous receptacle, and caespitose habit.

Cololobus argenteus has several unique characters that distinguish it from the other species of the genus, such as densely sericeous, panose, villose, tomentose trichomes, whitish and greyish, larger leaves (3.5-)4-12(-13.4) × 1.2-3.2(-4) cm, and pinkish pappus. Additionally, a combination of features also distinguish it from the remainder species of the genus, namely lanceolate and elliptic leaves, erect outter involucral bracts, covered by trichomes, pinkish, and magenta corolla (Tab. 1).

Cololobus argenteus morphologically resembles C. longiangustatus (G.M. Barroso) H.Rob., because they are robust caespitose subshrubs, with branches densely covered by trichomes, larger leaves, and larger capitula with $0.8-1.3 \mathrm{~cm}$ wide. However, $C$. argenteus is differentiated from $C$. longiangustatus by silvery trichomes in the entire plant (vs. brownish with moderately whitish trichomes in the branches); branches with densely sericeous and tomentose trichomes ( $v s$. densely tomentose, strigose); thinner leaves 1.2-3.2(-4) cm wide (vs. broader $2-5.5 \mathrm{~cm}$ wide); venation brochidodromous ( $v s$. eucamptodromous); inner involucral bracts with acuminate apex (vs. apex acute).

Cololobus argenteus has very dense greyish and silvery trichomes on branches and leaves and many imbricated leaves, which may be associated to reduction on leaf transpiration and foliar water uptake (Eller et al. 2013, 2016; Givnish et al. 1986; Lusa et al. 2014; Werker 2000), protection against excessive light and extreme temperatures (Lusa et al. 2014; Werker 2000), and fire (Clarke et al. 2013; Givnish 1986; Lusa et al. 2014). Additionally, wide, long and flexible inflorescences and pappus with bristles may be related to wind dispersal of fruits (Jeffrey 2009). These features might be seen putative ecological adaptations to inselberg, a very harsh environment (Larson 2000; Porembski 2007).

Vernonanthura spathulata M.Monge \& Semir, sp. nov. Type: BRAZIL. ESPÍRITO SANTO: Domingos Martins, Rio Jucu, 20.2911 ${ }^{\circ} \mathrm{S}$, $40.8350^{\circ} \mathrm{W}, 23$.VIII.2000, fl. and fr., O.J. Perreira 6394 (Holotype: UEC! Isotype: VIES!). Fig. 6

Vernonanthura spathulata is morphologically similar to $V$. discolor, but the new species differs by its leaves spathulated, obovated, oblanceolated, and rarely elliptic, attenuate base, retuse, obtuse or acute apex with a small mucron, principal venation striate abaxially, cream-colored trichomes on abaxial surface, and capitula with brownish trichomes.

Table 1 - Diagnostic characters of Cololobus argenteus compared with the remaining species of the genus.

\begin{tabular}{ccccc}
\hline Charcaters/species & C. argenteus & C. hatschbachii & C. longiangustatus & C. rupestris \\
\hline habit & $\begin{array}{c}\text { caespitose } \\
\text { subshrub }\end{array}$ & caespitose subshrub & caespitose subshrub & shrub \\
$\begin{array}{c}\text { Trichome persistence } \\
\text { on branches }\end{array}$ & persistent & partially glabrescent & persistent & glabrescent \\
$\begin{array}{c}\text { Trichome color } \\
\text { Prition of }\end{array}$ & silvery \& greyish & $\begin{array}{c}\text { brownish \& } \\
\text { moderately whitish }\end{array}$ & $\begin{array}{c}\text { moderately whitish } \\
\text { brownish \& }\end{array}$ & brownish \\
inflorescence & apical & apical \& axilar & apical \\
\hline
\end{tabular}




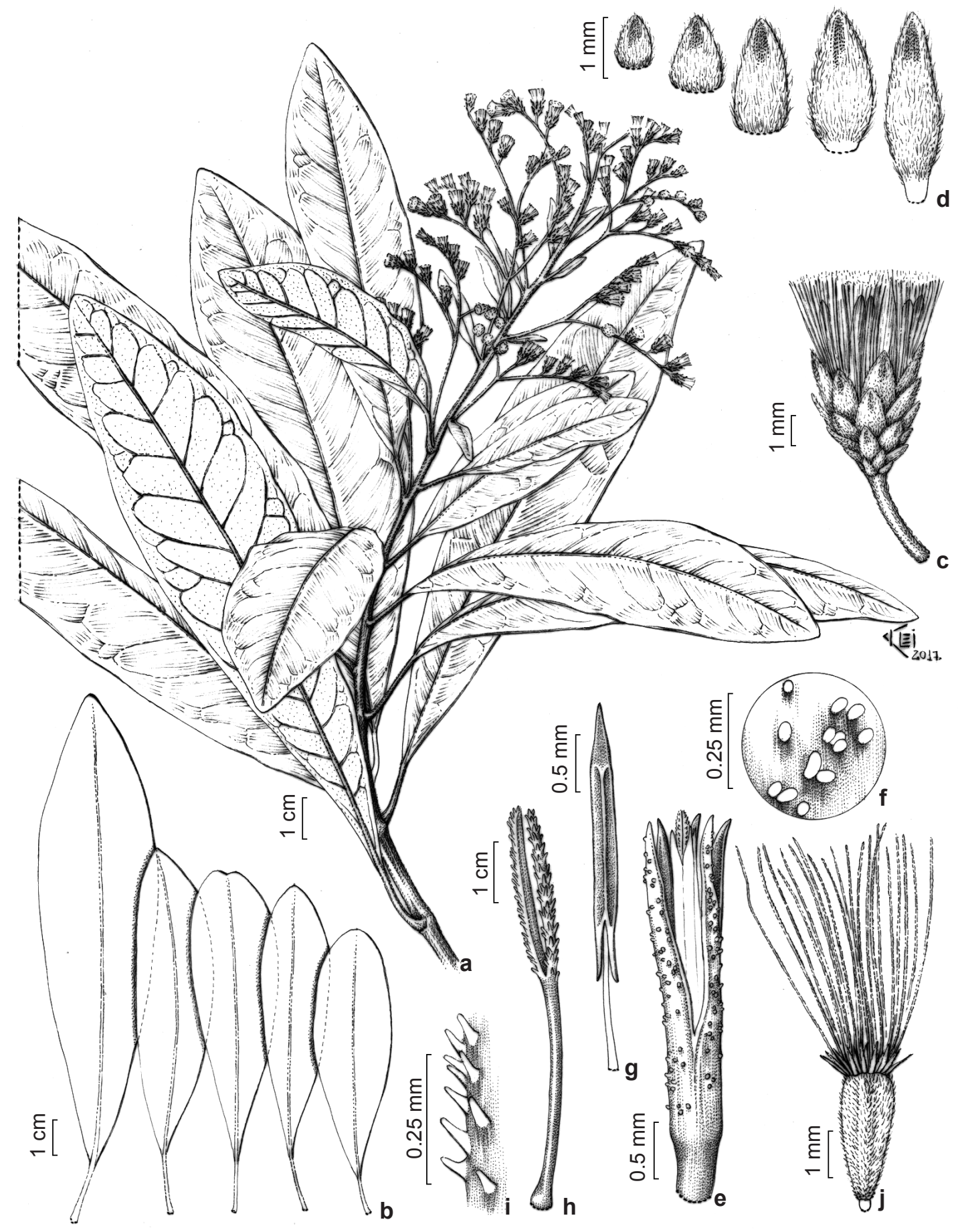

Figure 6-a-j. Vernonanthura spathulata - a. reproductive branch; b. leaf shape variation; c. involucre; d. involucral bracts; e. corolla; f. trichomes on corolla; g. anther; h. style; i. sweeping hairs; j. cypsela. (a., c-j. O.J. Perreira 6394; b. F. Zamborlini 55). 
Tree, up to $12 \mathrm{~m}$ tall. Branches striate, densely villous, mashed, brownish to ferruginous. Leaves alternate, petiolate, petiole $7-18 \mathrm{~mm}$, striate; lamina (3.6-)4-15 × (1-)2-4.2 cm, spathulate, obovate, oblanceolate, or rarely elliptic, base attenuate, sometimes asymmetric, margin smooth, revolute, apex obtuse, retuse, or rarely acute, with a small mucron; discolorous, abaxial surface densely villous, cream-colored, venation brownish, adaxial surface villous, glabrescent; venation brochidodromous, primary vein striate, secondary veins mixed opposite and alternate percurrent. Inflorescences in scorpioid cymes, sometimes forming corymbs, 4-7 capitula per cyme. Capitula 6-9 $\mathrm{mm}$, pedunculate, peduncle (2-)4-6 mm, densely villous, mashed, brownish to ferruginous, $2-3$ subinvolucral bracts present; involucre 5-6 $\times 4-6 \mathrm{~mm}$, straight campanulate, 5 series, 3 outer series, involucral bracts $1.1-1.7 \times 3-1.1 \mathrm{~mm}$, ovate, persistent, apex acute, margin ciliate, villous, puberulent, 2 inner series, involucral bracts $2.3-3.3 \times 1-1.5$ $\mathrm{mm}$, lanceolate, deciduous, apex acute, margin ciliose, puberulent, glabrescent. Receptacle plane, with smooth fruit scars, glabrous, epaleaceous. Flowers ca. 11 (young flowers), corolla $3 \mathrm{~mm}$, tubulose, glabrous, with glandular dots; anther 2.6-2.7 $\mathrm{mm}$, calcarate base, apical appendage elliptic, acute, non glandular: style base expanded, branches acute, sweeping hairs reaching below the bifurcation, unicellular, terete, apex rounded. Cypselae 1-3.3 mm, slightly obconical, striate, asymmetric, brown, pubescent, glandular dots at the base, carpopodium, $0.2 \mathrm{~mm}$, yellow; pappus 2 series, cream to whitish, inner row $4.5 \mathrm{~mm}$, bristle barbellate, outer row $0.8 \mathrm{~mm}$ long, narrow oblong.

Distribution, ecology, and conservation status: Vernonanthura spathulata is known only in the municipalities of Santa Teresa, in the Reserva Biologica de Santa Lúcia and Domingos Martins. Vernonanthura spathulata grows in the Ombrophilous Montane Forest, around 800-900 m of altitude (Fig. 2). Based on the estimates of the GeoCAT analysis, the new species is categorized as critically endangered (CR), following criteria $\mathrm{B} 1 \mathrm{ab}$ (i, iii) with an extension of occurrence (EOO) of $30.235 \mathrm{~km}^{2}$ and endangered (EN), according criteria $\mathrm{B} 2 \mathrm{ab}$ (ii, iii), with an area of occupancy (AOO) of $12 \mathrm{~km}^{2}$.

Phenology: The species was collected with very young capitula in July, developed fruits in October and November, and old capitula without fruits in March.
Etymology: The species name is due to very conspicuous obovate, spoon-like leaves.

Vernacular: Vassourão, louro-bravo, pautoucinho.

Additional specimens examined (Paratypes): BRAZIL. ESPÍRITO SANTO: Santa Teresa, Estação Ecológica Santa Lúcia, 820-855 m, 16.III.2004, fr., F. Zamborlini 55 (VIES 22390!); Reserva Biológica de Santa Lúcia, Mata de Encosta, $19.9358^{\circ} \mathrm{S}, 40.6000^{\circ} \mathrm{W}$, 9.XI.1993, fr., L.D. Thomaz 1610 (VIES!, UEC!); 650-820 m, 6.VII.1995, fr., L.D. Thomaz 1611 (VIES!, UEC!); $19.9358^{\circ} \mathrm{S}, 40.6000^{\circ} \mathrm{W}, 6 . X .1993$, fr., L.D. Thomaz 1614 (UEC!, VIES!).

Taxonomy: The new species is a tree with discolorous leaves, inflorescences in scorpioid cymes, few capitula per cyme, with few flowers per capitulum, and anthers with sagittate base. This new species belongs to the genus Vernonanthura due to the presence or large scorpioid cymes, glabrous corolla, enlarged stylar node, glands on the base of the fruits close to the carpopodium (Robinson 1992). The observed flowers are young; however, it has all the structures developed (corolla, gineceum, androecium, pappus, fruits, trichomes), and only the style base and the filament will present expansion.

Vernonanthura spathulata is morphologically similar to $V$. discolor due to the tree habit, discolorous leaves, very compact villous trichomes in the branches and abaxial leaf surfaces, and striate petioles and apical branches. However, these species are differentiated by the spathulate leaves, obovate, oblanceolate or rarely elliptic (vs. elliptic), abaxial leaf surface with trichomes cream-colored on blade and brown on the veins (vs. only white trichomes), attenuate leaf base ( $v s$. cuneate), leaf apex obtuse, retuse, rarely acute ( $v s$. acute), primary venation abaxially striate ( $v s$. half terete), capitula with brownish trichomes ( $v s$. whitish).

\section{Conclusions}

The description of five new species from three different lineages within Vernonieae in two regions considered conservation priorities (Ipema 2005) indicates the huge linnean shortfall as well as highlights that the current knowledge on biodiversity of the Atlantic Forest is incipient (Goldenberg et al. 2016), even in sites with decades of biological inventories, such as Santa Teresa (Thomaz \& Monteiro 1997; Fraga \& Kollmann 2003; Goldenberg \& Reginato 2006; Barbosa et al. 2012). Therefore, studies on biodiversity of the Atlantic Forest need to be encouraged, even in these areas in the tropics. 


\section{Acknowledgments}

The authors would like to thank Klei Souza for the line drawings, Bianca Vigna and Suzana Costa for reading the early version of the manuscript and Mayara Lima for reviewing the English version. We also would like to thank the editors and the two anonymous reviewers for the contribution on this publication, CAPES and $\mathrm{CNPq}$ for the scholarships, as well as FAPESP (2011/5190-3) for funding the visits to the herbaria.

\section{References}

Almeida RF \& Amorim A (2015) Stigmaphyllon mikaniifolium (Malpighiaceae), a new species Espírito Santo state, Brazil. Kew Bulletin 60: 1-7.

Bacci LF, Amorim AM \& Goldenberg R (2016) Three new species of Bertolonia (Melastomataceae) from Espírito Santo, Brazil. PeerJ 4: e2822.

Bachman S, Moat J, Hill A, de la Torre J \& Scott B (2011) Supporting red list threat assessments with GeoCAT: geospatial conservation assessment tool. ZooKeys 150: 117-126.

Barbosa TDM, Baitello JB \& Moraes PLR (2012) A família Lauraceae Juss. no Município de Santa Teresa, Espírito Santo. Boletim do Museu de Biologia Mello Leitão, Nova Série 30: 5-178.

BFG - The Brazil Flora Group (2015) Growing knowledge: an overview of seed plant diversity in Brazil. Rodriguésia 66: 1085-1113.

Brown KS Jr. (1972) Maximizing daily butterfly counts. Journal of Lepidopterologist's Society 23: 183-196.

Camargo EA \& Goldenberg R (2011) Two new species of Leandra (Melastomataceae) from Espírito Santo, Brazil. Brittonia 63: 220-226.

Carnaval AC \& Moritz C (2008) Historical climate modeling predicts patterns of current Biodiversity in the Brazilian Atlantic Forest. Journal of Biogeography 35: 1187-1201.

CEDAGRO (2012) Levantamento de áreas agrícolas degradadas no estado do Espírito Santo 1-63. Available at $<$ http://www.cedagro.org.br/ artigos/20121101104240_areas_Degradadas Documento_Completo.pdf $>$. Access on 22 April 2017.

Clarke PJ, Lawes MJ, Midgley JJ, Lamont BB, Ojeda F, Burrow GE, Enright NJ \& Knox KJE (2012) Resprouting as a key functional trait: how buds, protection and resources drive persistence after fire. New Phytologist 197: 19-35.

Eller CB, Lima AL \& Oliveira RS (2013) Foliar uptake of fog water and tranport belowground alleviates drought effects in the coud forest tree, Drimmys brasiliensis (Winteraceae). New Phytologist 199: 151-162.

Eller CB, Lima AL \& Oliveira RS (2016) Cloud forest trees with higher foliar water uptake capacity and anisohydric behavior are more vulnerable to drought and climate change. New Phytologist 211: 489-501.

Fraga CN \& Guimarães PJF (2014) Two new species of Pleroma (Melastomataceae) from Espírito Santo, Brazil. Phytotaxa 166: 77-84.

Fraga CN \& Kolmann LJC (2003) Myoxanthus ruschii (Orchidaceae), a new species from Brazilian Atlantic Forest, Espírito Santo. Novon 13: 49-51.

Fundação SOS Mata Atlântica \& Instituto Nacional de Pesquisas Espaciais (INPE) (2015) Atlas dos remanescentes florestais da Mata Atlântica Período 2013-2014. Fundação SOS Mata Atlântica, São Paulo. 70p.

Garbin ML, Saiter FZ, Carrijo TT \& Peixoto AL (2017) Breve histórico e classificação da vegetação capixaba. Rodriguésia 68: 1883-1894.

Goldenberg R, Michelangeli FA, Aona LYS \& Amorim AM (2016) Angiosperms and the Linneas shortfall: three new species from three lineages of Melastomataceae at one spot at the Altlantic Forest. PeerJ 4: e1824.

Goldenberg R \& Reginato M (2006) Sinopse da familia Melastomataceae na reserva Biológica de Santa Lúcia, Santa Teresa, Espírito Santo. Boletim do Museu de Biologia Mello Leitão, Nova Série 20: 33-58.

Givnish TJ, McDiarmid RW \& Buck WR (1986) Fire adaptation in Neblinaria celiae (Theaceae) a highelevation rosette shrub endemic to a wet equatorial tepui. Oecologia 70: 481-485.

IBGE (2012) Manual técnico da vegetação brasileira. $2^{\mathrm{a}}$ ed. IBGE, Rio de Janeiro. 271p.

Imig DC \& Cervi AC (2014) A new species of Passiflora L. (Passifloraceae), from Espírito Santo, Brazil. Phytotaxa 186: 292-296.

IPEMA - Instituto de Pesquisa da Mata Atlântica (2005) Áreas prioritárias para conservação da biodiversidade no Espírito Santo. Available at $<$ http//www.ipema-es.org.br/hp/mapas.htm $>$. Access on 25 April 2017.

IUCN (2016) Guidelines for using the IUCN red list categories and criteria. Version 12 . IUCN, Gland. $101 \mathrm{p}$.

Jeffrey C (2009) Evolutions of compositae flowers. In: Funk V, Susanna A, Stuessy TF \& Bayer RJ (eds.) Systematics, evolution, and biogeography of Compositae. IAPT, Vienna: 131-138.

Keeley SC, Forsman ZH \& Chan R (2007) A phylogeny of the "evil tribe" (Vernonieae: Compositae) reveals Old/New World long distance dispersal: support from separate and combined congruent datasets (trnL1, ndhF, ITS). Molecular Phylogenetics and Evolution 44: 89-103.

Keeley SC \& Robinson H (2009) Vernonieae. In: Funk V, Susanna A, Stuessy TF \& Bayer RJ (eds.) Systematics, evolution, and biogeography of Compositae. IAPT, Vienna. Pp. 439-469. 
Larson DW, Mathes U \& Kelly PE (2000) Cliff ecology: patterns and process in cliff ecosystems. Cambridge University Press, Cambridge. 340p.

LAWG (1999) Manual of leaf architecture: morphological description and categorization of dicotyledonous and net-veined monocotyledonous angiosperms. Smithsonian Institution, Washington. $65 \mathrm{p}$.

Leme EMC, Fontana AP \& Hallbritter H (2010) Three new Pitcairnia species (Bromelicaceae) from inselbergs of Espírito Santo, Brazil. Systematic Botany 35: 487-496.

Lusa MG, Appezzato-da-Glória B, Loeuille B, Bartoli G \& Ciccarelli D (2014) Functional groups in Lychnophorinae (Asteraceae: Vernonieae) based on morphological and anatomical traits. Australian Journal of Botany 62: 150-163.

Moreira DO, Coutinho BR \& Mendes SL (2008) O status do conhecimento sobre a fauna de mamíferos do Espírito Santo baseado em registros de museus e literatura científica. Biota Neotrópica 8: 163-173.

Morellato LPC \& Haddad CF (2000) Introduction: the Brazilian Atlantic Forest. Biotropica 32: 786-792.

Myers N, Mittermeier RA, Mittermeier CG, Fonseca GAB \& Kent J (2000) Biodiversity hotspots for conservation priorities. Nature 403: 853-858

Oliveira-Filho AT \& Fontes MAL (2000) Patterns of floristic differentiation among Atlantic Forests in southeastern Brazil, and the influence of climate. Biotropica 31: 793-810.

Porembski S (2007) Tropical inselberg: habitat types, adaptative strategies and diversity patterns. Revista Brasileira de Botânica 30: 579-586.

Radford AE, Dickison WC, Massey JR \& Bell CR (1974) Vascular plant systematics. Harper \& Row, New York. 891p.

Ribeiro MC, Metzger JP, Martensen AC, Ponzoni FJ \& Hirota MM (2009) The Brazilian Atlantic Forest: how much is left, and how is the remaining forest distributed? Implications for Conservation. Biological Conservation 142: 1141-1153

Robinson H (1988) Studies in the Lepidaploa complex (Vernonieae: Asteraceae). IV: the new genus Lessingianthus. Proceedings of the Biological Society of Washington 101: 929-951.

Robinson H (1990) Studies in the Lepidaploa complex (Vernonieae: Asteraceae). VII: the genus Lepidaploa. Proceedings of the Biological Society of Washington 103: 464-498.

Robinson H (1992) A new genus Vernonanthura (Vernonieae, Asteraceae). Phytologia 73: 65-76.

Robinson H (1994) Cololobus, Pseudopiptocarpha, and Trepadonia, three new genera from South America (Vernonieae: Asteraceae). Proceedings of the Biological Society of Washington 103: 557-568.

Robinson H (1999) Generic and subtribal classification of American Vernonieae. Smithsonian Contributions to Botany 89: 1-116.
Robinson H (2002) Three new species of Piptocarpha (Asteraceae: Vernonieae) from Ecuador and Peru. Novon 12: 393-398.

Robinson H (2007) Vernonieae. In: Kubitski EdK, Kadereit JW \& Jeffrey C (eds.) The families and genera of vascular plants: flowering plants, Eudicots: Asterales. Vol. 8. Springer-Verlag, Berlin, Heideberg. Pp. 149-174.

Robinson H, Bohlmann F \& King RM (1980) Chemosystematic notes on the Asteraceae III: Natural subdivisions of the Vernonieae. Phytologia 46: 420-436.

Saiter FZ \& Thomaz LD (2014) Revisão da lista de espécies arbóreas do Inventário de Thomaz \& Monteiro (1997) na Estação Biológica de Santa Lúcia: o mais importante estudo fitossociológico em florestas montanas do Espírito Santo. Boletim do Museu de Biologia Mello Leitão, Nova Série 43: 101-128.

Sala OE, Chapin FS, Armesto JJ, Berlow E, Bloomfield J, Dirzo R, Huber-Sanwald E, Huenneke LF, Jackson RB, Kinzig A, Leemans R, Lodge DM, Mooney HÁ, Oesterheld M, Poff NL, Sykes MT, Walker BH, Walker M \& Wall DH (2000) Global diversity scenarios for the year 2100 . Science 287 : 1770-1774.

Sales MF, Kinoshita LS \& Simões AO (2006) Eight new species of Mandevilla Lindley (Apocynaceae, Apocynoideae) from Brazil. Novon 16: 112-128.

Simon JE (2009) A lista de aves do estado do Espírito Santo. Caderno de Resumo do XVII Congresso Brasileiro de Ornitologia, Capítulos especiais. Available at $<$ http://www.ceo.org.br/listas_de aves/lista_es_simon.pdf $>$. Access on 15 November 2017.

Simon JE \& Padovan MP (2000) Composição da avifauna da Estação Biológica de Santa Lúcia, Santa Teresa - ES. Boletim do Museu de Biologia Mello Leitão, Nova Serie 11: 149-170.

Smith GL (1981) New taxa in Piptocarpha R.Br. (Vernonieae: Compositae). Annals of Missouri Botanical Garden 68: 661-667.

Smith GL (1982) Taxonomic considerations of Piptocarpha (Compositae: Vernonieae) and new taxa in Brazil. Brittonia 34: 201-218.

Smith GL (1984) Revision of Piptocarpha R.Br. PhD Thesis. University of Georgia, Athens. 247p.

Smith GL \& Jones SB (1987) Cytotaxonomic studies of Piptocarpha subgenus Hypericoides (Compositae: Vernonieae). Rhodora 88: 35-40.

Smith GL \& Coile NC (2007) Piptocarpha (Compositae: Vernonieae). Flora Neotropica Monograph 99: $1-94$.

Sobral M (2005) Eugenia inversa (Myrtaceae), a new species from Espírito Santo, Brazil. SIDA 21: 1465-1469.

Thiers B [continuamente atualizado] Index herbariorum: a global directory of public herbaria and associated 
staff. New York Botanical Garden's Virtual Herbarium. Available at $<$ http://sweetgum.nybg. org/science/ih/>. Acccess on 5 March 2017.

Thomaz LD (2010) A Mata Atlântica no estado do Espírito Santo, Brasil: de Vasco Fernandes Coutinho ao século 21. Boletim do Museu de Biologia Mello Leitão, Nova Série 27: 5-20.
Thomaz LD \& Monteiro R (1997) Composição florística da Mata Atlântica de encosta da Estação Biológica de Santa Lúcia, município de Santa Teresa-ES. Boletim do Museu de Biologia Mello Leitão, Nova Série 7: 3-48.

Werker E (2000) Trichome diversity and development. Advances in Botanical Research 31:1-35. 